\title{
BANDING IN AORTIC STENT-GRAFT FIXATION IN EVAR
}

\author{
Petr Utíkala, Martin Köcher ${ }^{\mathrm{b}}$, Petr Bachleda ${ }^{\mathrm{a}}$, Petr Dráča ${ }^{\mathrm{a}}$ Marie Černác, Eva Buriánkovác \\ a 2nd Clinic of Surgery, Teaching Hospital Olomouc \\ ${ }^{b} \quad$ Clinic of Radiology, Teaching Hospital Král. Vinohrady Praha \\ Clinic of Radiology, Teaching Hospital Olomouc, Czech Republic \\ e-mail:petr.utikal@fnol.cz
}

Received: October 7, 2004; Accepted: October 25, 2004

Key words: Aorta/Aneurysms/Repair/Endovascular/Stent-graft/Fixation/Endoleak/Migration/Complications

The authors describe the method of surgical aortic banding for better stent-graft fixation in cases of problematic aortic neck in the endovascular infrarenal aneurysms repair.

\section{INTRODUCTION}

Endovascular infrarenal aneurysm repair (EVAR) has its technical limitations caused by the present-day stentgraft systems ${ }^{1}$. Stentgraft fixation, especially in the proximal aortic neck, is one of them. AAAs with problematic proximal neck- short (from 5 to $15 \mathrm{~mm}$ ), conical or with a long enough but angulated one - were excluded from EVAR preserving classical stentgrafting indications criteria due to the problematic stentgraft fixation ${ }^{2-4}$. The basic types of fixation such as stent-graft self-expansion, barbs, hooks or suprarenal bare wire fixation in the more stable part of aorta are not adequate in these cases of proximal neck anatomy ${ }^{5-9}$. One possibility for providing successful stent-graft fixation is the use of associated surgery - external aortic banding ${ }^{10}$.

\section{METHOD}

We indicated proximal aortic banding in 6 patients during our EVAR period from the year $1996^{11,12}$. Aortic banding was primarily indicated for problematic stentgraft anchoring in an angulated proximal neck $(n=2)$ and in a short conical one $(n=2)$. Secondary banding was used to resolve proximal perigraft leak $(n=2)$, which developed within 2 years of primary technicaly successful EVAR due to proximal neck dilation.

The banding procedures were done in regional (epidural) anesthesia. The infrarenal aorta was exposed through transperitoneal approach - a small mini-laparotomy to the left of the umbilicus. The strip of dacron prosthesis was tightened firmly around the aorta just below the renal arteries origins with two sutures. A baloon dilatation in stent-graft was used to ensure adequate expansion (Fig. 1, Fig. 2).

The procedure took about 30 minutes. Angiography and CTA were performed for check. Technical success was achieved in all patients. There were no relevant gen- eral or local complications arising from the higher invasiveness of this procedure. All the patients are alive till this time and are observed in mean duration 3 years without any signs of perigraf endoleak or other stent-graft related complications.

\section{DISCUSSION}

Surgical proximal aortic banding may be created as prevention or solution perigraft leak, migration and aortic neck dilatation ${ }^{13,14}$. "Primary banding" refers to associated surgery from the first step of AAA evaluation and we decide in favor of this approach before stentgraft planning. Primary banding makes EVAR possible. "Secondary banding" is the term used for banding in complications solution. Laparoscopic banding creation is an alternative, but pneumoperitoneum induced by insuflation puts more stress on the patient than a small open access ${ }^{15}$. In cases of a short neck, a fenestrated graft should be an acceptable alternative at present ${ }^{16}$. The branched graft is going to be the method of choice in the nearest future ${ }^{17}$.

\section{CONCLUSION}

Aortic banding provides a stable fixation of stent-graft. In cases of problematic proximal aortic neck can make the EVAR possible and minimalise the risk of its failure. This associated surgical procedure has acceptable risk for the patients and it is easy, feasibile and safe. 

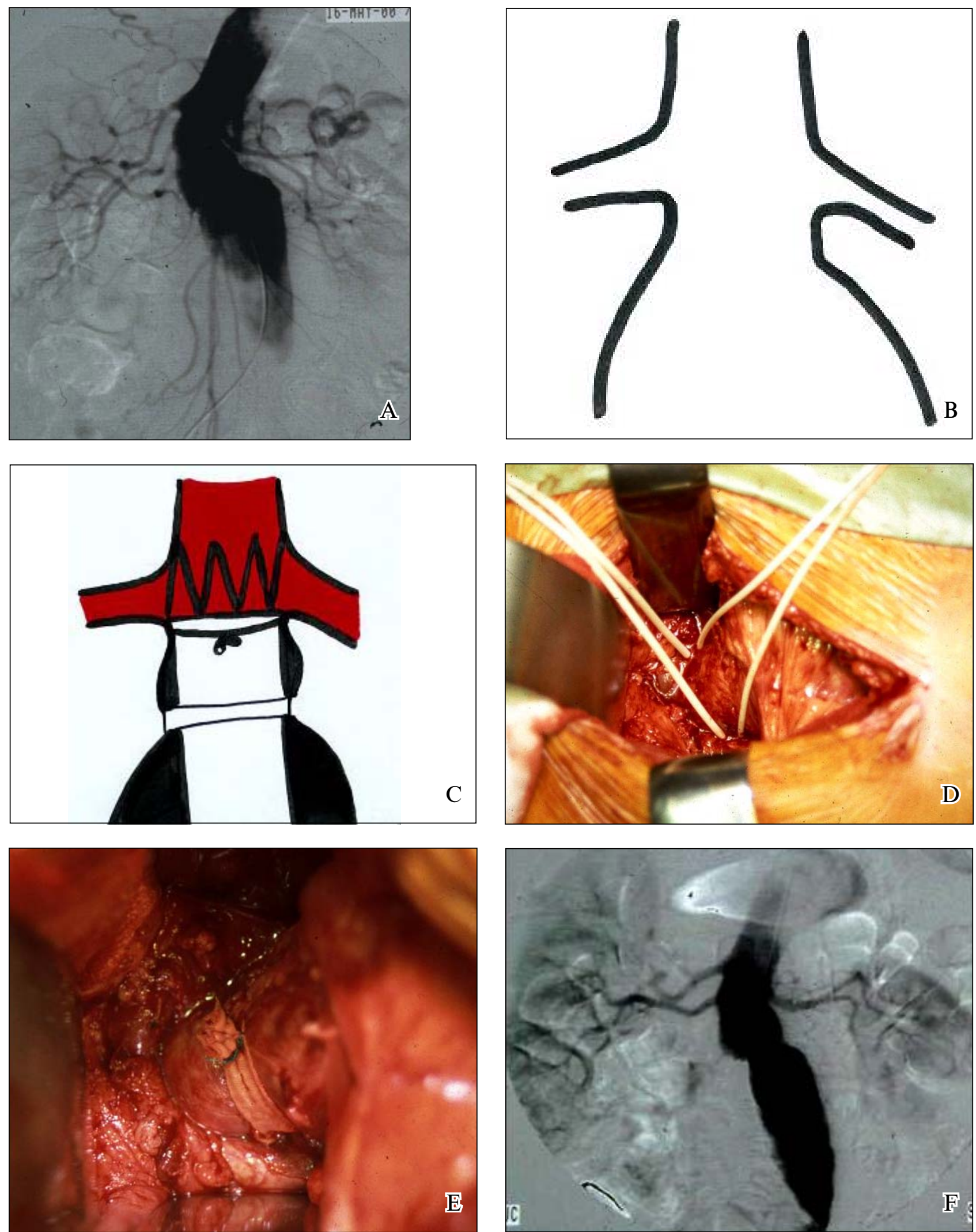

Fig. 1. A 75 year old man of high operating risk with complicated AAA morphology

A: Preoperative angiogram of AAA with a short conical proximal neck

B, C: Diagram of the short conical proximal aortic neck and neck banding.

D, E: Operating access and peroperative view of the infrarenal aorta with proximal neck banding - a strip of dacron prosthesis

F: Postoperative angiogram of successful EVAR by uniiliac type of stent-graft associated with proximal aortic neck banding 

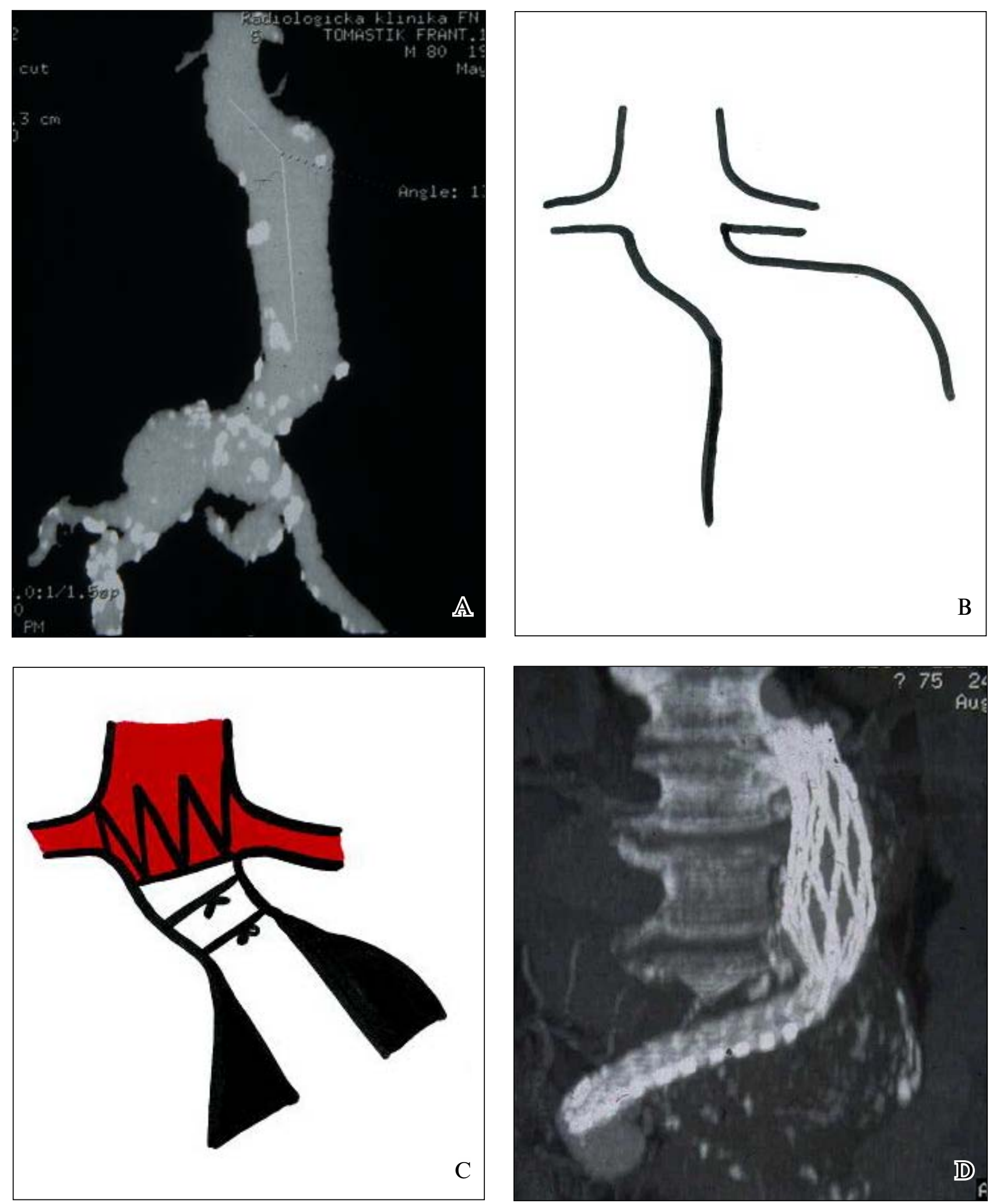

Fig. 2. A 68 year old man of high operating risk with complicated AAA morphology

A: Preoperative CTA of AAA with an angulated proximal neck

B, C: Diagram of the angulated neck and neck banding

D: Postoperative CTA of succesful EVAR by uniiliac type of stent-graft associated with proximal neck banding. 


\section{REFERENCES}

1. Parodi JC, Palmaz JC, Barone HD. (1991) Transfemoral intraluminal graft implantation for abdominal aortic aneurysms. Ann Vas Surg 5, 4912-499.

2. Schumacher H, Allenberg JR, Eckstein HH. (1996) Morphological classification of abdominal aortic aneurysm in selection of patients for endovascular grafting. Br J Surg 83, 949-950.

3. Carpenter JP, Baum RA, Barker CF. (2001) Impact of exclusion criteria on patient selection for endovascular abdominal aortic aneurysm repair. J Vasc Surg 34, 1050-1054.

4. Schumacher H, Eckstein HH, Kallinowski F. Morphometry and classification in abdominal aortic aneurysms: patient selection for endovascular and open surgery. J Endovasc Surg 4, 39-44.

5. Mangell P, Malina M, Vogt K. (1996) Self-expanding stents are superior to baloon expanded in dilating aortas- An experimenta study in pigs. Eur J Vasc Endovasc Surg 12, 287-294.

6. Malina M, Lindblat B, Ivancev K. (1998) Will stents with hooks and barbs prevent stent-graft migration? J Endovasc Surg 5, 310317.

7. Morrissey NJ, Faries PL, Teodorescu V, Hollier L, Marin ML. (2002) Transrenal bare stents in endovascular treatment of abdominal aortic aneurysm. J Invasive Cardiol 14, 36-40.

8. Bove PG, Long GW, Zelenock GB, Bendick PJ, Khoury MD, Burr MO, Bechtel G, Becker F, Huckabone C. (2000) Transrenal fixation of aortic stentgrafts for treatment of infrarenal aortic aneurysmal disease. J Vasc Surg 32, 697-703.

9. Resch T, Malina M, Lindblad B, Malina J, Brunkwall J, Ivancev K. (2000) The impact of stent design on proximal stent-graft fixation in the abdominal aorta: an experimental study. Eur J Vasc Endovasc Surg 20, 190-195.
10. Sonesson B, Montgomery A, Ivancev K, Lindblad B. (2001) Fixation of infrarenal aortic stent-grafts using laparoscopic bandig- an experimental study in pigs. Eur J Vasc Endovas Surg 21, 40-45.

11. Utíkal P, Köcher M, Bachleda P, Dráč P, Buriánková E, Kojecký Z, Ürge J. (2001) Léčba AAA na přelomu tisíciletí - stentgrafting - role cévního chirurga. Prakt Flebol 10, 111-113.

12. Köcher M, Utíkal $\mathrm{P}$, , Koutná J, Bachleda $\mathrm{P}$, Buriánková E, Heřman M, Bučil J, Benýšek V, Černá M, Kojecký Z. (2004) Endovascular treatment of abdominal aortic aneurysms- 6 years of experience with Ella stent-graft system. Eur J of Radiol 51, 181-188.

13. Sonneson B, Malina M, Ivancev K. (1998) Dilatation of the infrarenal aneurysm neck after endovascular exclusion of abdominal aortic aneurysm. J Endovasc Surg 5, 195-200.

14. Resch T, Ivancev K, Brunkwall J. (1999) Distal migration of stentgrafts after endovascular repair of abdominal aortic aneurysms. J Vasc Intervent Radiol 10, 257-264.

15. Alimi YS, Hartung O, Orsoni P, Juhan C. (2000) Abdominal aortic laparoscopic surgery: retroperitoneal or transperitoneal approach? Eur J Vasc Endovasc Surg 19, 21-26.

16. Verhoeven ELG, Prins TR, Tielliu IFJ, van den Dungen JJAM, Zeebregts CJAM, Hulsebos RG, van Andringa de Kempenaer MG, Oudkerk M, van Schilfgaarde R. (2004) Treatment of short-necked infrarenal aortic aneurysms with fenestrated stent-grafts: short term results. Eur J Vasc Endovasc Surg 27, 477-483.

17. Vos AWF, Linsen MAM, Wisselink W, Rauwerda JA. (2004) Endovascular grafting of complex aortic aneurysms with a modular side branch stent-graft system in a porcine model. Eur J Vasc Endovasc Surg 27, 492-497. 